Article

\title{
Does the Choice of IJV under Institutional Duality Promote the Innovation Performance of Chinese Manufacturing Firms? Evidence from Listed Chinese Manufacturing Companies
}

\author{
Chong Wu ${ }^{1, *} \mathbb{D}$, Siyi Bo ${ }^{1}$, Xing Wan ${ }^{2, *}$, Min Ji ${ }^{1}$, Meihua Chen ${ }^{1}$ and Shifan Zhang ${ }^{1}$ \\ 1 Business School, Nanjing University of Information Science \& Technology, Nanjing 210044, China; \\ 20191225001@nuist.edu.cn (S.B.); 002213@nuist.edu.cn (M.J.); 20201225001@nuist.edu.cn (M.C.); \\ 20191225006@nuist.edu.cn (S.Z.) \\ 2 Business School, Nanjing University of Finance \&Economics, Nanjing 210046, China \\ * Correspondence: 002063@nuist.edu.cn (C.W.); wanxing@nufe.edu.cn (X.W.)
}

Received: 29 July 2020; Accepted: 20 August 2020; Published: 24 August 2020

\begin{abstract}
The relationship between the strategic choice of internationalization under institutional duality and the performance of emerging market multinational enterprises (EM-MNEs) will become a focal point for scholars, practitioners and policy makers in the future. In order to better understand the determinants of the entry mode choice under institutional duality for EM-MNEs, based on the sample of Chinese manufacturing listed companies 'going out' from 2003 to 2015, we investigated the impact of organization institutional inertia and host-country institutional quality on the choice of the international joint venture (IJV) of Chinese manufacturing firms, as well as the effect and potential problems of the IJV choice on the firms' innovation performance under institutional duality. The main results of our empirical analyses provide evidence that the response to institutional duality means that Chinese firms have the possibility to choose IJV in entry modes ahead of their capability support, and subject to insufficient professional field accumulation, cross-cultural management and joint governance capability, this premature choice of IJV actually hinders their innovation efficiency. Furthermore, the test on the influence of firm heterogeneity found that, when the firm is privately owned or has a lower internationalization breadth, the above negative moderating effect of IJV choice is more significant. Our findings enrich the literature on the relationship between the strategic choice of internationalization and innovation performance of EM-MNEs, and provide inspiring and straightforward empirical evidence.
\end{abstract}

Keywords: emerging economies; outward foreign direct investment; international joint venture; firm innovation performance

\section{Introduction}

After 2000, the Chinese government found that traditional technology import or export trade could not effectively enhance the international competitiveness and independent innovation capability of Chinese firms. Therefore, the government officially proposed the 'going out' strategy, which was an important opening-up measure in 2001 [1]. Unlike the foreign direct investment (FDI) previously emphasized by the government, according to the definition in China's Outward Foreign Direct Investment (OFDI) Bulletin, 'going out' refers to OFDI behavior. That is to say, "Chinese firms and organizations invest in foreign countries and Hong Kong, Macao and Taiwan, in the form of cash, physical objects, intangible assets, etc., and take controlling the operation and management right of overseas firms as the core and economic activities" [2]. The Chinese government wants Chinese 
firms to 'go out', establishing wholly-owned subsidiary (WOS) or international joint ventures (IJV) and extensively entering the host country market, so as to achieve their goals of acquiring strategic resources and improving their innovation capability. Besides this, in order to cope with the pressure of foreign trade barriers and dependence on technology introduction, the pace of OFDI in China's manufacturing industry has been accelerating in recent years [3]. Therefore, since 2004, two years after the implementation of the 'going out' strategy, the scale and speed of the 'going out' of China's manufacturing industry have been increasing continuously. Data from the Statistical Bulletin of China's Outward Foreign Direct Investment shows that the number of OFDI manufacturing firms rose rapidly, from 1749 in 2004 to 5748 at the end of 2011, with an average annual growth rate of 18.5\%. During the implementation of China's 12th Five-Year Plan (2011-2015), China's manufacturing industry accounted for $12.1 \%$ of China's total OFDI in 2015, while in the first year of the implementation of the 13th Five-Year Plan (2016-2020), the proportion of China's manufacturing industry accounted for $18.3 \%$ of China's total OFDI. Since 2018, the amount of Chinese firms' OFDI in the manufacturing sector has been the largest, accounting for $49.6 \%$ of the total, and it continues to be the most popular industry for China's overseas investment. This shows that, in response to the government's encouragement and the pressure of 'anti-globalization', many manufacturing firms have conducted a lot of OFDI without the gradual accumulation of internationalization, and China's 'going out' manufacturing firms generally show a trend of leapfrog development of internationalization [4].

Unlike the global market expansion under the 'monopolistic advantage driven' and 'location advantage driven' strategies pursued by multinational enterprises (MNEs) in developed economies, under the background of internationalization leapfrog development, latecomer firms' OFDI in emerging economies has the dual mission of transferring excess production capacity and seeking innovative technologies [5]. Moreover, the further development of Chinese firms' OFDI shows that their market-oriented OFDI is weakening, while their resource-oriented and technology-oriented OFDI are increasing. In other words, more and more Chinese firms are shifting their OFDI from Asia and Africa to developed economies such as Europe and America to acquire strategic resources [6]. Furthermore, in terms of entry mode choice, as a primary strategic choice of Chinese OFDI manufacturing firms to enter the international markets, more and more Chinese firms are gradually adopting the IJV mode, and breaking away from the WOS mode which they used to be good at under the internal control style. This is because every MNE subsidiary is not only exposed to the intra-organization institutional field, but additionally to host-country institutional environments, a situation termed 'institutional duality' [7-11]. As a consequence, in the situation of both organization institutional constraints and host-country institutional pressures, especially the legitimacy pressures from host-country institutional quality and differences, Chinese firms increase the possibility of choosing IJV in entry modes out of the encouragement of the government and overconfidence, and in response to the pressures of host-country institutional quality and differences [12,13]. However, in the stage of internationalization leapfrog development, because of insufficient capabilities in professional accumulation, cross-cultural management and joint governance, their existing behavioral patterns and organizational practices are inevitably in conflict with the current internationalization strategy to some extent, meaning that their strategic choice is ahead of their capability support, which greatly restricts their internationalization effectiveness [14,15].

Although some studies examine how firm-level factors (such as firm size, asset specificity and international experience) and host-country institutional factors (such as investment uncertainty, demand uncertainty and cultural distance) support firms' entry mode choice and performance [16,17], they are still confined to the MNEs of developed countries. Especially in the context of technology-oriented OFDI form EM-EMNs, prior studies lack further research on the determinants and effects of the entry mode choice of latecomer firms under institutional duality $[18,19]$. Thus, under the background of the leapfrog development of Chinese firms' internationalization, a significant research field on the relationship between the entry mode choice of latecomer firms and innovation growth will become a focal point for scholars, practitioners and policy makers in the future $[19,20]$. However, 
under the background of the leapfrog development of latecomer firms' internationalization, there are few empirical studies on the determinants of premature IJV choices under institutional duality and the impacts of premature IJV choice on the innovation performance of latecomer firms, especially the above-mentioned causal identifications and potential problems from the perspective of firm heterogeneity. In fact, as the primary strategic choice for EM-MNEs to enter the international market, the entry mode directly affects the efficiency of their innovative resources' integration, absorption and reconstruction. Therefore, in order to achieve a better innovation efficiency during internationalization, it is required that their professional field accumulation and cross-cultural management capabilities match their strategic choices [21].

Therefore, in the stage of leapfrog internationalization, what are the determinants of the IJV choice under institutional duality for EM-MNEs? Does the premature IJV choice under institutional duality have a negative impact on the innovation performance of latecomer firms which lack their capabilities support? Furthermore, in transition countries like China, do Chinese firms' heterogeneity, as in ownership structure and internationalization breadth, have important impacts on the above causal relationship? In order to respond to the above problems, tracking the periodic influence and potential problems of premature IJV choice on the innovation performance of Chinese firms, the structure of this paper is as follows: firstly, we match the firms which had OFDI projects from 2003 to 2015 in the 'Overseas Investment Firm List' published by the Chinese Ministry of Commerce with "industrial firms in the database of Shanghai and Shenzhen A shares" in the same period to select samples of listed companies in the manufacturing industry with OFDI experience. Although the number of samples is very limited, this study can provide significant data and propose methods that can be used for further research on EM-MNEs.

Secondly, from the perspective of dual responses to organization institutional factors and host-country institutional factors, this paper combines IJV and innovation performance in a theoretical framework. This study analyses the impact of organization institutional inertia and host-country institutional quality on the choice of IJV of Chinese manufacturing firms, as well as the impact of IJV choice under institutional duality on the innovation performance of firms, and analyses the moderating effect of IJV on the relationship between R\&D input and innovation performance from the perspective of firm heterogeneity.

Finally, this study examines straightforward empirical evidence and suggests future research ideas for research on the relationship between MNEs' internationalization and their performance. We hope that it will provide a new theoretical perspective and practical inspiration for the research on the relationship between the internationalization strategy choice and innovation performance of the latecomer firms.

\section{Literature Review and Hypotheses}

\subsection{The Choice of IJV under Institutional Duality}

The complex institutional environment under institutional duality brings many difficulties and challenges to the strategic choice and behavior of the overseas subsidiaries of firms $[8,22]$. At present, there is still limited research on how organizations respond to the conflict pressure from the institutional duality environment, especially the lack of relevant researches on EM-MNEs [21,23]. However, the choice of strategy or entry mode under the institutional duality response can enable MNEs to better respond to the pressure of internal and external institutional environment, so as to achieve a balance of 'legitimacy' between organizational inertia and host-country environment. On the one hand, the choice of entry mode is often constrained by organization institutional inertia; namely, the restriction of firm ownership, the risk of asset specificity and the role of international experience accumulation. On the other hand, in terms of the formal institution quality and the informal institution differences in the host country, the choice of entry mode is also affected by the institution response of the host country; namely, the stability of the host country's economic mechanism, the level of the 
rule of law, and other formal institution quality factors, as well as the cultural distance factors in the informal institution [24]. Therefore, the relationship between the strategic choice of internationalization under institutional duality and the performance of EM-MNEs will become a focal point for scholars, practitioners and policy makers in the future.

\subsubsection{The Influence of Organization Institutional Factors on the IJV Choice}

Under the perspective of institutional duality, the choice of entry mode is generally constrained by the organizations' institutional inertia [10]. Research focused on Western firms pointed out that the choice of the organizational mode of MNEs' overseas subsidiaries is based on the characteristics of three organization institutional factors; namely, ownership, asset specificity and international experience accumulation. First of all, from the perspective of institution and resource integration, ownership forms the basic characteristics of the organization institution of Chinese firms. China's state-owned firms have more political objectives and tasks $[25,26]$. Moreover, the decision-making and incentives of top managers in terms of strategy, investment and personnel are also constrained by political tasks and objectives [27]. Therefore, state-owned firms controlled by the government mostly shoulder the mission of obtaining strategic resources and technological innovation breakthroughs [28]. In order to accomplish political tasks and goals, their overseas branches generally tend to adopt the IJV mode to enter the local market in efficiency-oriented mergers and acquisitions [29,30]. Secondly, as we all know, asset specificity is divided into materials, places, brands, and human resources, and the level of investment in durable assets is a general indicator that is used to assess asset specificity [31]. Specific assets are investments made that have less value outside the specific transactional relationship [32]. The transaction cost perspective believes that, with the increase of asset specificity, firms' fixed assets or technical assets will lose value in alternative uses, which increases the opportunistic risk. Therefore, when the asset specificity is high, MNEs will try their best to choose the WOS mode, so as to improve economic efficiency by a high degree of property right control, a high degree of resource commitment and a low risk of knowledge diffusion [33]. Finally, from the perspective of organizational capability, in the process of continuously investing resources in foreign markets to acquire international market knowledge, such knowledge will directly transform into the organization institutional factors of MNEs, affecting their decisions on further investment in the market. When it comes to the advanced stage of international experience accumulation, due to the pursuit of advanced technology and multipole innovation, MNEs will enter the host-country market extensively through IJV or alliances with local firms [34]. Accordingly, the following hypothesis is proposed:

Hypothesis 1 (H1). The control of state ownership, lower asset specificity and more early international experience increase the possibility of adopting IJV by Chinese firms.

\subsubsection{The Influence of Host-Country Institutional Factors on the IJV Choice}

Under the perspective of institutional duality, the choice of entry mode is also affected by the quality of the formal institution and the distance of the informal institution in the host country [11]. From the perspective of institutional theory, the institutional factors of the host country have an important influence on the entry mode choice of MNEs. From the perspective of a formal institution, scholars have proposed that the political and economic risks of the host country are only one aspect of the institutional environment of the host country, and the legal restrictions and intellectual property protection of the host country are the institutional environmental factors that have an important impact on the organizational mode choice of MNEs. The more advanced the institutional level of the host country, the more inclined the firms are to choose to establish wholly-owned subsidiaries [16]. In this regard, scholars believe that the more perfect of the host-country economic mechanism is, the more stable the economic operation will be. Otherwise, economic uncertainty will bring high market transaction costs to MNEs. Economic uncertainty arises from political instability, economic fluctuations, currency changes and other volatility in a firm's environment [11]. The transaction cost 
theory suggests that, in ephemeral environments, entrants are better off accepting low-control entry modes [35,36]. Therefore, when economic volatility—such as demand, tax and exchange rate-is relatively large, MNEs prefer the joint venture or alliance mode, which is conducive to resource complementation and interactive learning, out of the need to share risks or reduce the time cost of innovation [37]. In addition, some scholars have explained the influences on MNEs' transaction cost from the perspective of legal perfection of host country. Among them, the investment protection risks such as the industrial protection, contract quality and income distribution affect the 'transaction cost' of MNEs operating in the host country [33]. Therefore, when the host country has a high risk in legal institution, it will lead to market inefficiency and higher market transaction costs. Therefore, due to the demand of opportunistic risk avoidance, MNEs tend to learn local market knowledge and develop local resources through cooperation with local firms [38].

From the perspective of informal institutions, the choice of organizational mode of an MNEs' overseas subsidiary should not only serve its own interests, but also comprehensively consider the impact of the internalized codes of conduct and difference of values in the host country [39]. Among them, scholars of 'institutional adaptation theory' attribute the normative and cognitive distance between home country and host country to the difference of informal institutions, and habitually measure it by cultural distance [40]. Empirical results on the influence of cultural distance on the choice of organizational mode of MNEs' overseas institutions are mixed. Some scholars have found that, in the case of high cultural distance, MNEs may prefer IJV with low control, to make up for their lack of knowledge and rely on local partners to contribute local knowledge [41]. The greater the cultural distance between the home country and the host country, the higher the knowledge barriers MNEs face, and the more management and innovation costs firms have to bear [42]. Therefore, they are inclined to choose the overseas organizational mode of joint ventures or alliances [43]. Studies by other scholars suggest, however, that the wholly-owned mode under the high control of overseas institutions may be more effective in giving MNEs specific advantages that cannot be easily copied by other firms, which helps them to compete with local firms by operating in a way that is far from the local culture [44]. Accordingly, the following hypothesis is proposed:

Hypothesis 2 (H2). The greater economic operation risk, rule of law risk and cultural distance increase the possibility of adopting IJV by Chinese firms.

\subsection{The Influence of IJV Choice on Firm Innovation Performance: A Perspective of the International Leapfrog Development Stage}

In recent years, due to the needs of economic development, the Chinese government and local governments at all levels have encouraged qualified Chinese firms to 'go out' as soon as possible. However, under the condition that they have not experienced the staged accumulation processes of 'commodity exportation-sales subsidiary-investment to set up factories', many Chinese firms have invested excessively in overseas markets, and China's manufacturing industry shows a trend of international leapfrog development [4]. Secondly, in terms of the mode of entry, IJV have become the main mode for Chinese firms to enter foreign markets in order to bypass trade barriers and, at the same time, meet the challenges of the complex institutional environment of the host country. This is because, on the one hand, although interactive learning and innovation in the process of going out have contributed to the international competitiveness of Chinese firms, in the face of the pressure from the institutional quality and differences in host countries, Chinese firms have increased their response to the host-country institutional quality and differences in terms of entry mode choices. On the other hand, under the influence of government intervention, weak specific assets and early internationalization experience; namely, the above situation of institutional duality affects their IJV choices, and their IJV choice under institutional duality also has an important influence on the innovation performance of the parent firm by the reverse transfer of knowledge in their overseas business [26,45]. Moreover, from the perspective of organizational learning theory, learning, knowledge acquisition and adaptability 
development are the important theoretical basis for MNEs to choose IJV, and have a significant impact on the innovation performance of MNEs. In the process of IJV, the two parties use the new knowledge and skills acquired by each other to improve their competitive position and their capabilities, so that the partnership in the IJV can be continuously maintained, and they can gain a competitive advantage in the market [46].

In general, under great pressure from unstable economic operations, imperfect legal institutions and a large cultural distance, such as the host country's dissociative identity disorder to the foreign state-owned firms, restrictions of mergers and acquisitions or restrictions on establishing WOS, Chinese firms will increase the choice of IJV to better respond to the pressure from host-country institutional duality and differences [47]. However, for the latecomer firms in the above-mentioned international leapfrog development stage, such IJV will aggravate the negative impact of their own insufficient internationalization on their innovation performance at the present stage. This is because the adjustment of the organizational mechanism of latecomer firms in emerging economies generally lags behind their needs for technological innovation, and the integration capability of local innovation networks-such as cross-cultural management and joint governance-cannot be improved in the short term [48]. Therefore, such a premature IJV choice, which ignores the constraints of internationalization capabilities, will have an adverse impact on their innovation activities. Thus, we propose the following hypothesis:

Hypothesis 3 (H3). Constrained by the lack of internationalization capabilities in the leapfrog development stage, the choice of IJV generally has a negative impact on firm innovation performance.

\subsection{The Influence of IJV Choice on Firm Innovation Performance: A Perspective of Firm Heterogeneity}

\subsubsection{The Perspective of Differences in Firm Ownership}

With the development of OFDI by firms in transition countries such as China, scholars have gradually paid more attention to the influence of differences in firm ownership. From the perspective of the leapfrog development stage of internationalization, most Chinese 'going out' firms are generally weak in their core professional competence, which is more obvious for private firms lacking support in scale, strength, financial policies and other aspects, which greatly increases the asymmetry of their status and position in IJV [49]. Therefore, the influence of IJV on the innovation performance of latecomer firms in emerging economies needs to consider the impact of the heterogeneity of firm ownership. In this regard, compared with private firms, the political ties of state-owned firms can bring more convenience to themselves. They are more likely to obtain resources, concessions, support and assistance from the home country, which are often difficult for private firms to reach and obtain [50-52]. For example, financial constraints and government-led credit rationing have also accelerated the professional capacity building and international growth of state-owned firms to some extent. Therefore, compared with private firms, state-owned firms can better resist various uncertainties and risks in the process of international cooperation [53-55]. In short, in the face of an unfamiliar host-country institutional environment, market environment and local partners, compared with state-owned firms, private firms lack the relative advantages in terms of policy and financial support, and professional competence and international capability are relatively insufficient, which to some extent restrains their status and position in IJV, and to some extent strengthens the negative impact of the choice of IJV on their innovation. Accordingly, the following hypothesis is proposed:

Hypothesis 4 (H4). Compared with state-owned firms, the IJV choice of private firms has a more significant inhibitory effect on innovation performance.

\subsubsection{The Perspective of Differences in Firm Internationalization Breadth}

In terms of transferring production capacity and seeking innovative technologies, EM-MNEs tend to enter multiple overseas markets. In other words, this kind of 'market-seeking' or 'technology-seeking' 
foreign investment can easily gain economies of scale and economies of scope by entering multiple overseas markets [56]. Moreover, with the increasing geographical distance and cultural distance in the development of multiple overseas markets, firms are more able to access the resources, technology, management and experience of the different cultures of various countries. The differences brought by geographical diversification are also conducive to the in-depth organization learning of firms, as well as the capability to develop diversified entry modes such as strategic alliances, $R \& D$ alliances and joint ventures to adapt to the needs of multinational markets [57,58]. Therefore, the impact of IJV on the innovation performance of latecomer firms in emerging economies also needs to consider the impact of differences in the degree of the internationalization of firms. This is because, with the geographic diversification brought about by the increase of internationalization breadth, in order to adapt to the diversified host-country institutional and multinational market environment, this will prompt the firm to increase the tendency to imitate and learn from the local partners, and then develop and accumulate the capability to choose and apply IJV modes, and accordingly increase the capability of cross-cultural management and joint governance with the local partners [6,59]. On the contrary, the low internationalization breadth means that firms lack diversified learning opportunities-such as cross-cultural management and joint governance-which hinders the effective accumulation of their experience and capabilities in international cooperation, which to some extent strengthens the negative impact of IJV choice on their innovation performance. Accordingly, the following hypothesis is proposed:

Hypothesis 5 (H5). Compared with firms with higher internationalization breadth, the IJV choice of firms with lower internationalization breadth has a more significant inhibitory effect on innovation performance.

Based on the above assumptions, the conceptual model of this paper is shown in Figure 1.

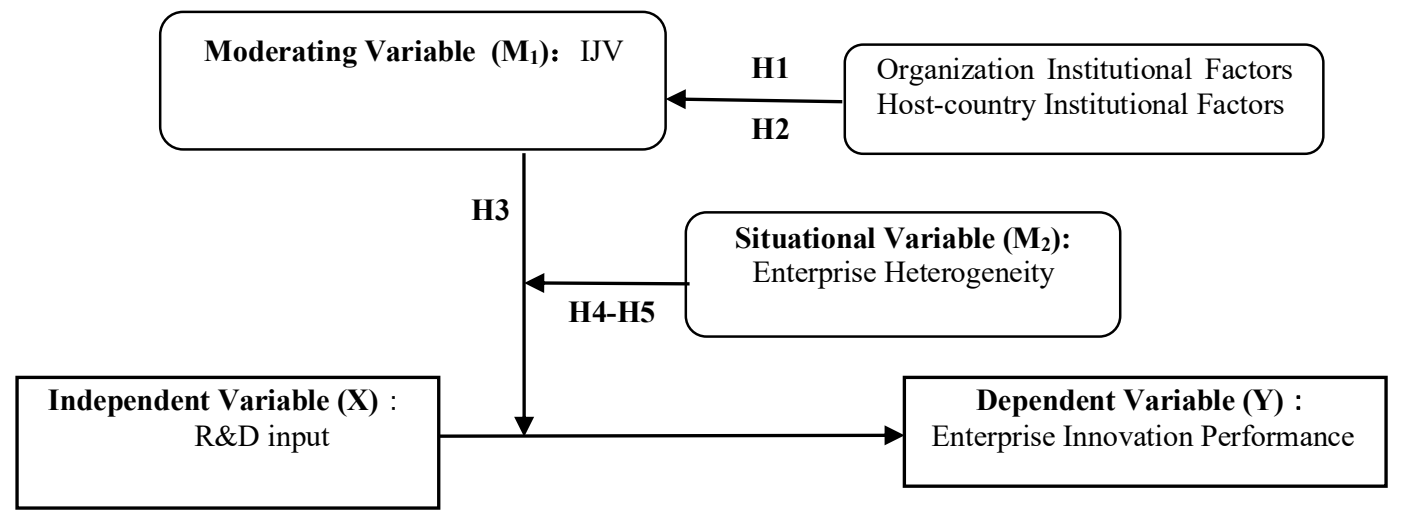

Figure 1. Conceptual model.

\section{Research Methodology and Data}

\subsection{Sample Selection and Data Sources}

The sample data of the firms was selected to match the OFDI firms in the 'List of Overseas Investment Firms (Institutions)' on the website of the ministry of commerce, with 'industrial firms (code industry)' in the same period of listed companies in Shanghai and Shenzhen A-shares and gem in the CSMAR database. Then, the data was filtered according to the following principles: (1) remove samples without industrial experience in OFDI; (2) remove samples with unclear business scope of overseas subsidiaries and no accumulation of R\&D activities in the annual report; (3) remove the samples with asset reorganization and changes to the main business within three years after OFDI; (4) remove samples with incomplete disclosure of financial and patent data within three years after OFDI. Based on this, 243 observations with relatively complete data indicators from 2003 to 2015 in OFDI manufacturing firms were selected. The data from 2003 to 2015 were selected for the following 
reasons. Firstly, the Chinese government began to put forward the slogan of firms 'going out' in 2001. After a short period of preparation, it began to promote the concept in 2003, and accelerated the pace of firms 'going out' in 2004. Secondly, it involves the feasibility and standardization of data statistics. Since the China Securities Regulatory Commission (CSRC) revised and published the requirements of the code of corporate information disclosure content and format for public securities issuance No. 2 (content and format of the annual report) at the end of 2003, listed companies generally improved the timeliness, accuracy, truthfulness and completeness of information disclosure. Considering the accuracy and timeliness of the samples, this paper takes 2003 as the starting point and selects the samples of the listed manufacturing companies of the OFDI from 2003 to 2015. The company-level data comes mainly from the annual reports of listed companies, and a few missing effective invention patent data are supplemented by the 'China Patent Full-text Database' of the State Intellectual Property Office.

\subsection{Research Design}

For Hypothesis 1 and Hypothesis 2, we employed Model 1 to investigate the entry mode choice (Equation (1)):

$$
I J V_{i t}=\beta_{0}+\beta_{1} \text { Owner }_{i, t}+\beta_{2} S P_{i . t}+\beta_{3} F S T S_{i, t}+\beta_{4} E P_{i, t}+\beta_{5} L a w_{i, t}+\beta_{6} C D_{i, t}+\mu
$$

For Hypothesis 3, Hypothesis 4 and Hypothesis 5, in the regression of the firms' innovation performance, the performance regression equation (Model 2) was designed with explanatory variables, regulatory variables and control variables, and the regression equation of the moderating effect of IJV on 'R\&D input (RDIN—firm innovation performance (Lnpat)' is constructed by Equation (2):

$$
\text { Lnpat }_{i, t}=\alpha_{0}+\alpha_{1} \operatorname{RDIN}_{i, t}+\alpha_{2} I J V_{i, t}+\alpha_{3} I J V_{i, t} \times \operatorname{RDIN}_{i, t}+\sum_{j=1}^{5} \beta_{j} \text { Control }_{j}+\varepsilon
$$

Among them, the dependent variables, independent variables, moderating variables and other control variables are detailed in the following index design and data description. In addition, in order to eliminate the possible errors of missing variables and reverse causality, and achieve reliable estimates, this paper selects two instrumental variables for R\&D input. According to Lewbel's [60] method, the first takes (Firm Innovation Performance-Average Value of Firm Innovation Performance) $\times$ (Firm R\&D Input-Average Firm R\&D Input) as the first instrumental variable. The characteristic of this method is that an effective instrumental variable can be constructed without the help of external variables. The second instrumental variable adopts the proportion of R\&D personnel in firms in the first three years of the OFDI. Generally speaking, the proportion of R\&D personnel in the first three years is positively correlated with the independent variable of the current R\&D input, and has a weak relationship with the firms' innovation performance of the current period, which satisfies the exogenous and relevance conditions.

\subsection{Variables and Data}

\subsubsection{Dependent Variables}

International joint venture (IJV): the dummy variable (IJV) is used to represent the two ownership entry modes; the joint venture mode is represented by 1 , and the WOS entry mode is represented by 0 .

Firm innovation performance (Lnpat): here, the natural logarithm of the annual number of new invention patent applications of the firms is used as the proxy index of innovation output. In addition, in order to avoid the special case where the observed value is 0 , we added one to the actual values when calculating the natural logarithm [61]. 


\subsubsection{Independent or Control Variables}

Ownership (Owner): a dummy variable whose value is 1 represents a state-owned firm, while 0 represents a private firm.

Firm scale (Lnsize): the natural logarithm of total assets.

Asset specificity (SP): the ratio of fixed assets to total assets at the end of the year before firms' OFDI.

Early international experience (FSTS): in order to measure the early international marketing experience of Chinese manufacturing firms based on export trade and technology introduction, the ratio of overseas revenue to total revenue (FSTS) at the end of the year before firms' OFDI is used to measure their early international experience [62].

Host country economic fluctuation (EP): existing studies generally claim that, when the economic institution in a host country is more perfect, that institution will be more stable, and the economic fluctuations are smaller; otherwise, there will be a large fluctuation in demand and supply. We used GDP-related data obtained from the World Bank and the rolling variance of GDP growth rate over a seven-year period to measure economic uncertainty, because short economic fluctuation cycles in different countries are normally shorter than seven years.

Degree of rule of law development (Law): the development of the rule of law in the host country is measured by the 'rule of law' in the World Governance Indicators (WGI) published by the World Bank [63].

Degree of investment protection (IP): this indicator comes from the host country's investment status index (Investment Profile) in the International Reporting Group's (ICRG) National Risk Report. The higher the score, the higher the degree of institutional protection for foreign investment in the country.

Cultural distance (CD): Hofstede's score of five cultural dimensions was used to calculate the cultural distance between the home country and the host country by referring to the calculation formula of Tihanyi et al. [64] (Equation (3)):

$$
C D_{C \cdot \mathrm{w}}=\frac{\sum_{x=1}^{5}\left[\left(I_{x C}-I_{x w}\right)^{2} / V_{x}\right]}{5}
$$

In Equation (3), $C D_{C \cdot \mathbf{w}}$ represents the cultural distance between China and country $\mathbf{w}, I_{x C}$ is the score of dimension $x$ of China, $I_{x w}$ is the score of dimension $x$ of country $w$, and $V_{x}$ is the variance of the score of dimension $x$.

R\&D input (RDIN): we use the ratio of R\&D expenditure to main business revenue in the following three years after OFDI to measure the innovation investment $[65,66]$.

\subsubsection{Moderating Variables}

Entry mode (IJV): is consistent with the variable definition in the first stage of the IJV mode choice regression.

\subsubsection{Categorical Variables}

Ownership (Owner): is consistent with the variable definition in the second stage of the firm innovation performance regression.

Internationalization breadth (Breadth): in order to compare with the early internationalization experience (FSTS) based on export and technology import, and to measure the localization capabilities of firms in transnational operations, we use the cumulative total number of countries where firms set up subsidiaries for the first time in different countries to measure the internationalization breadth of the firms. The greater the value is, the greater the strategic flexibility of firms to integrate innovative resources with the economic scope of multiple national markets will be $[67,68]$. 


\section{Empirical Results}

The mean value, standard deviation (SD) and correlation coefficient matrix of the variables in the regression model are listed in Table 1; the lower left corner is the Pearson correlation coefficient, and the upper right corner is the Spearman correlation coefficient. As can be seen from Table 1 (1) the correlation coefficients between the main variables were all less than 0.50 , and the variance inflation factor (VIF) was much less than 10; this excludes the possibility of collinearity between the main variables; however, the effectiveness of the regression model design requires further verification of the possibility of collinearity in the subsequent regression analysis using the maximum variance inflation factor method. (2) The level of firm innovation indicators was uneven, and RDIN and IJV were positively and negatively correlated with Lnpat, respectively. Therefore, this is consistent with the hypothesis in this paper that a premature IJV choice has a negative impact on the innovation of firms in the stage of international leapfrog development.

Table 1. Descriptive statistics of the main variables and the Pearson/Spearman correlation.

\begin{tabular}{|c|c|c|c|c|c|c|c|c|c|c|}
\hline Variable & Mean & SD & Lnpat & RDIN & IJV & Lnsize & SP & FSTS & IP & CD \\
\hline Lnpat & 3.902 & 1.864 & 1 & $0.172 * * *$ & $-0.113^{*}$ & $0.447^{* * *}$ & $-0.187^{* * *}$ & $-0.267^{* * *}$ & -0.102 & -0.049 \\
\hline RDIN & 0.073 & 0.079 & 0.035 & 1 & -0.022 & $-0.199^{* * *}$ & $-0.174^{* * *}$ & 0.001 & $-0.143^{* *}$ & 0.089 \\
\hline IJV & 0.255 & 0.437 & $-0.119 *$ & 0.053 & 1 & 0.074 & -0.101 & 0.084 & $-0.164^{* *}$ & -0.012 \\
\hline Lnsize & 21.88 & 1.142 & $0.440^{* * *}$ & $-0.178^{* * *}$ & 0.066 & 1 & $-0.139 * *$ & $-0.372^{* * *}$ & $-0.122 *$ & 0.015 \\
\hline SP & 0.235 & 0.133 & $-0.221^{* * *}$ & $-0.139^{* *}$ & -0.086 & $-0.114 *$ & 1 & $0.128^{* *}$ & -0.033 & 0.064 \\
\hline FSTS & 0.300 & 0.268 & $-0.235^{* * *}$ & -0.044 & 0.090 & $-0.357^{* * *}$ & 0.078 & 1 & -0.052 & 0.041 \\
\hline IP & 10.93 & 1.533 & -0.014 & -0.070 & $-0.192^{* * *}$ & -0.103 & -0.056 & -0.026 & 1 & $-0.190^{* * *}$ \\
\hline $\mathrm{CD}$ & 3.208 & 1.889 & -0.030 & $0.159 * *$ & 0.019 & 0.006 & 0.023 & 0.080 & -0.023 & 1 \\
\hline
\end{tabular}

\subsection{The Choice of IJV under Institutional Duality}

Table 2 displays Logistic regression results based on regression equation (1). It can be seen from the table that the chi-square value of Model 3, which represents the dual-response of institutional factors, compared with Model 1 of organization institutional factors' response and Model 2 of host-country institutional factors' response, are 17.54 and 15.12, respectively, which are significant at the $1 \%$ level. This indicates that the theoretical model under the dual-response of organization institutional factors and host-country institutional factors has a better prediction effect, and it effectively predicts $77.31 \%$ of the sample firms' choice of IJV. In addition, Owner, FSTS and EP have significant positive effects on IJV, and SP has significant negative effects on IJV, which is consistent with the main expected parts of H1 and H2. However, as mentioned in the literature review, the effects of cultural distance are mixed, and have not been significantly verified in empirical tests. The results show that the government's intervention in firms through state-owned holding, the low level of internationalization experience based on export trade, the low asset specificity caused by the lack of accumulation in professional fields, and the inertia of these organizational institutions increases the propensity of firms to choose IJV. In addition, the weak institutional quality of the host countries, such as economic volatility and uncertainty caused by the imperfect rule of law, significantly increases the likelihood of Chinese firms choosing IJV. 
Table 2. Logistic regression analysis of the IJV choice.

\begin{tabular}{|c|c|c|c|}
\hline Variable & Model 1 & Model 2 & Model 3 \\
\hline Owner & $\begin{array}{c}1.132 * * * \\
(0.393)\end{array}$ & & $\begin{array}{c}1.216^{* * *} \\
(0.418)\end{array}$ \\
\hline SP & $\begin{array}{l}-1.925 \\
(1.305)\end{array}$ & & $\begin{array}{c}-2.440 * \\
(1.401)\end{array}$ \\
\hline FSTS & $\begin{array}{l}1.653 * * \\
(0.648)\end{array}$ & & $\begin{array}{l}1.669 * * \\
(0.684)\end{array}$ \\
\hline $\mathrm{EP}$ & & $\begin{array}{l}8.115^{* *} \\
(3.398)\end{array}$ & $\begin{array}{l}8.504^{* *} \\
(3.556)\end{array}$ \\
\hline Law & & $\begin{array}{l}-0.017^{* *} \\
(0.009)\end{array}$ & $\begin{array}{l}-0.019 * * \\
(0.009)\end{array}$ \\
\hline CD & & $\begin{array}{l}-0.003 \\
(0.095)\end{array}$ & $\begin{array}{c}0.018 \\
(0.100)\end{array}$ \\
\hline Constant & $\begin{array}{l}-3.157^{* *} \\
(1.429)\end{array}$ & $\begin{array}{l}-0.241 \\
(1.232)\end{array}$ & $\begin{array}{c}-3.955^{* *} \\
(1.744)\end{array}$ \\
\hline Observations & 243 & 243 & 243 \\
\hline chi2 & 28.56 & 30.98 & 46.10 \\
\hline r2_p & 0.103 & 0.112 & 0.167 \\
\hline 11 & -123.7 & -122.5 & -115.0 \\
\hline $\begin{array}{c}\text { LRtest } \\
-2[\mathrm{~L}(\mathrm{red})-\mathrm{L}(\mathrm{full})] \backsim \chi 2 \text { based on Model } 1\end{array}$ & & & $17.54^{* * *}$ \\
\hline $\begin{array}{c}\text { LRtest } \\
-2[\mathrm{~L}(\mathrm{red})-\mathrm{L}(\mathrm{full})] \backsim \chi 2 \text { based on Model } 2\end{array}$ & & & $15.12^{* * *}$ \\
\hline Overall Prediction Accuracy & $70.43 \%$ & $73.04 \%$ & $77.31 \%$ \\
\hline
\end{tabular}

\subsection{The Influence of IJV Choice on Firm Innovation Performance}

Table 3 is a full-sample regression based on regression equation (2), which mainly examines the impact of the IJV choice on firms' innovation performance. Moreover, in order to test the robustness of the results, considering that the dependent variable Lnpat is a trailing variable with a lower limit of 0 , this paper also adopts the Tobit model for regression, and makes comparative estimation with OLS regression. Table 3 reports the results of the Tobit regression and OLS regression.

(1) Control variables: (1) the coefficients of Lnsize in models 1 to 6 are significantly positive above the $1 \%$ level. This shows that, in the rapid development stage of China's manufacturing industry, the visibility and authority of large-scale firms in the integration of social resources, government support and financial support, as well as the leading firms in the field of organization, provide favorable conditions for them to acquire strategic resources and promote innovation. (2) The coefficients of SP in models 1 to 6 are significantly negative above the $5 \%$ level. This shows that too much asset specificity resulting from the low capability accumulation of the professional field of Chinese firms at the current stage, to some extent, hampers the driving power of the transformation from traditional tangible asset investment to innovative intangible asset, and has a inhibiting effect on firm innovation. (3) The coefficients of FSTS are negative and insignificant in models 1 to 6 . This also shows that, compared with the strong localization capabilities of mature MNEs, the early foreign marketing experience of Chinese manufacturing generated by export trade or technology introduction has no significant impact on firm innovation [69].

(2) Explanatory variables: the coefficients of RDIN in models 1 to 6 are all significantly positive above the $5 \%$ level, indicating that R\&D input has a significant promotion effect on firm innovation performance. The coefficients of the interaction terms IJV $\times$ RDIN in model 3 and model 6 are significantly negative above the $10 \%$ level. This shows that, in the stage of international leapfrog development, combined with the analysis of the influence of the above control variables on firm innovation, the accumulation of professional fields and the development of the internationalization 
capabilities of Chinese manufacturing firms at the current stage lags behind the needs of innovation and internationalization; that is to say, the lack of asset integration, cross-cultural management, joint governance and other capabilities generally leads to a premature IJV choice that produces a negative moderating effect on firm innovation, which is consistent with Hypothesis 3.

Table 3. Regression of the relationship between the IJV choice and firms' innovation performance.

\begin{tabular}{|c|c|c|c|c|c|c|c|c|c|}
\hline \multirow{2}{*}{ Variable } & Model 1 & Model 2 & Model 3 & Model 4 & Model 5 & Model 6 & Model 7 & Model 8 & Model 9 \\
\hline & \multicolumn{3}{|c|}{ OLS Regression } & \multicolumn{3}{|c|}{ Tobit Regression } & \multicolumn{3}{|c|}{ IV (2sls) } \\
\hline RDIN & $\begin{array}{c}2.981^{* *} \\
(1.392)\end{array}$ & $\begin{array}{l}3.077^{* *} \\
(1.382)\end{array}$ & $\begin{array}{c}5.065^{* * *} \\
(1.753)\end{array}$ & $\begin{array}{c}3.267^{* *} \\
(1.414)\end{array}$ & $\begin{array}{l}3.374^{* *} \\
(1.401)\end{array}$ & $\begin{array}{c}5.225^{* * *} \\
(1.772)\end{array}$ & $\begin{array}{l}-0.143 \\
(2.833)\end{array}$ & $\begin{array}{c}0.209 \\
(2.794)\end{array}$ & $\begin{array}{l}9.915^{*} \\
(5.873)\end{array}$ \\
\hline IJV & & $\begin{array}{c}-0.522 * * \\
(0.248)\end{array}$ & $\begin{array}{l}-0.141 \\
(0.323)\end{array}$ & & $\begin{array}{c}-0.558^{* *} \\
(0.252)\end{array}$ & $\begin{array}{l}-0.199 \\
(0.328)\end{array}$ & & $\begin{array}{c}-0.680^{* * *} \\
(0.245)\end{array}$ & $\begin{array}{c}-0.663^{* * *} \\
(0.249)\end{array}$ \\
\hline IJV $\times$ RDIN & & & $\begin{array}{c}-4.915^{*} \\
(2.691)\end{array}$ & & & $\begin{array}{c}-4.610^{*} \\
(2.728)\end{array}$ & & & $\begin{array}{c}-13.163 \text { ** } \\
(6.042)\end{array}$ \\
\hline Lnsize & $\begin{array}{c}0.708^{* * *} \\
(0.104)\end{array}$ & $\begin{array}{c}0.734 * * * \\
(0.104)\end{array}$ & $\begin{array}{c}0.731^{* * *} \\
(0.103)\end{array}$ & $\begin{array}{c}0.714^{* * *} \\
(0.106)\end{array}$ & $\begin{array}{c}0.743^{* * *} \\
(0.105)\end{array}$ & $\begin{array}{c}0.740 * * * \\
(0.105)\end{array}$ & $\begin{array}{c}0.641 * * * \\
(0.112)\end{array}$ & $\begin{array}{c}0.668^{* * *} \\
(0.111)\end{array}$ & $\begin{array}{c}0.752 * * * \\
(0.124)\end{array}$ \\
\hline SP & $\begin{array}{c}-1.803^{* *} \\
(0.830)\end{array}$ & $\begin{array}{c}-2.023^{* *} \\
(0.831)\end{array}$ & $\begin{array}{c}-2.019 * * \\
(0.826)\end{array}$ & $\begin{array}{c}-1.970 * * \\
(0.846)\end{array}$ & $\begin{array}{c}-2.207^{* * *} \\
(0.844)\end{array}$ & $\begin{array}{c}-2.196^{* * *} \\
(0.838)\end{array}$ & $\begin{array}{c}-2.383^{* * *} \\
(0.848)\end{array}$ & $\begin{array}{c}-2.565^{* * *} \\
(0.835)\end{array}$ & $\begin{array}{c}-2.000 \text { ** } \\
(0.910)\end{array}$ \\
\hline FSTS & $\begin{array}{r}-0.430 \\
(0.416)\end{array}$ & $\begin{array}{l}-0.318 \\
(0.416)\end{array}$ & $\begin{array}{l}-0.356 \\
(0.414)\end{array}$ & $\begin{array}{l}-0.423 \\
(0.422)\end{array}$ & $\begin{array}{l}-0.304 \\
(0.421)\end{array}$ & $\begin{array}{l}-0.338 \\
(0.419)\end{array}$ & $\begin{array}{l}-0.557 \\
(0.438)\end{array}$ & $\begin{array}{l}-0.410 \\
(0.434)\end{array}$ & $\begin{array}{l}-0.303 \\
(0.448)\end{array}$ \\
\hline IP & $\begin{array}{l}-0.011 \\
(0.071)\end{array}$ & $\begin{array}{l}-0.039 \\
(0.071)\end{array}$ & $\begin{array}{l}-0.037 \\
(0.071)\end{array}$ & $\begin{array}{l}-0.006 \\
(0.072)\end{array}$ & $\begin{array}{l}-0.036 \\
(0.073)\end{array}$ & $\begin{array}{l}-0.034 \\
(0.072)\end{array}$ & $\begin{array}{c}0.016 \\
(0.071)\end{array}$ & $\begin{array}{l}-0.018 \\
(0.071)\end{array}$ & $\begin{array}{c}0.007 \\
(0.073)\end{array}$ \\
\hline $\mathrm{CD}$ & $\begin{array}{l}-0.093 \\
(0.058)\end{array}$ & $\begin{array}{l}-0.093 \\
(0.058)\end{array}$ & $\begin{array}{c}-0.101 \text { * } \\
(0.057)\end{array}$ & $\begin{array}{l}-0.097 \\
(0.059)\end{array}$ & $\begin{array}{c}-0.098^{*} \\
(0.058)\end{array}$ & $\begin{array}{c}-0.104 * \\
(0.058)\end{array}$ & $\begin{array}{l}-0.021 \\
(0.059)\end{array}$ & $\begin{array}{l}-0.022 \\
(0.058)\end{array}$ & $\begin{array}{l}-0.070 \\
(0.065)\end{array}$ \\
\hline _cons & $\begin{array}{c}-13.737^{* * *} \\
(2.657)\end{array}$ & $\begin{array}{c}-14.024^{* * *} \\
(2.641)\end{array}$ & $\begin{array}{c}-14.028^{* * *} \\
(2.627)\end{array}$ & $\begin{array}{l}-14.327^{* * *} \\
(2.711)\end{array}$ & $\begin{array}{c}-14.663 \text { *** } \\
(2.690)\end{array}$ & $\begin{array}{l}-14.644^{* * *} \\
(2.671)\end{array}$ & $\begin{array}{l}-11.876^{* * *} \\
(2.753)\end{array}$ & $\begin{array}{l}-12.119^{* * *} \\
(2.709)\end{array}$ & $\begin{array}{c}-14.373^{* * *} \\
(3.060)\end{array}$ \\
\hline Year & yes & yes & yes & yes & yes & yes & yes & yes & yes \\
\hline $\mathrm{N}$ & 243 & 243 & 243 & 243 & 243 & 243 & 243 & 243 & 243 \\
\hline $\mathrm{F} / \mathrm{chi}^{2}$ & 6.573 & 6.549 & 6.445 & 95.06 & 99.93 & 102.8 & 11.72 & 11.43 & 10.19 \\
\hline $\mathrm{R}^{2} /$ PseudoR $^{2}$ & 0.332 & 0.345 & 0.354 & 0.095 & 0.100 & 0.103 & 0.229 & 0.255 & 0.227 \\
\hline Adj. $R^{2} / 11$ & 0.281 & 0.292 & 0.299 & -451.3 & -448.8 & -447.4 & 0.209 & 0.233 & 0.200 \\
\hline First Stage F Value & & & & & & & 16.39 & 14.32 & 12.01 \\
\hline Sargan-Hansen test [ $p$-Value] & & & & & & & 0.7833 & 0.6506 & 0.4461 \\
\hline
\end{tabular}

Notes: ${ }^{*} p<0.10,{ }^{* *} p<0.05,{ }^{* * *} p<0.01 ; t$-values are in parentheses.

In addition, this paper further used the two-stage instrumental variable method (IV-2SLS) to test the robustness of the above conclusions. First of all, the F statistics of the first-stage regression are all above the empirical value of 10 , indicating that the selected instrumental variables are highly correlated with endogenous explanatory variables, and the problem of 'weak instrumental variables' can be excluded. Secondly, the over-identified test of instrumental variables was carried out, and results of the Sargan-Hansen statistical test were not significant. This result means that it is impossible to reject the null hypothesis that all of the variables were exogenous, and indicates that the instrumental variables we selected were relatively effective. The coefficient of the interaction item IJV $\times$ RDIN in Model 9 is significantly negative above the $5 \%$ level, which is consistent with the two regression results of the OLS and Tobit, and the $p$-values of the HAUSMAN statistic test in the comparison between the OLS and instrumental variable method are both below $10 \%$, which means the OLS regression results are reliable. Hypothesis 3 has been verified. The results show that, in the stage of leapfrog development, Chinese firms lack the capability to support the choice of advanced IJV, which significantly inhibits the innovation performance of firms.

\subsection{The Influence of IJV on Firms' Innovation Performance: A Perspective of Firm Ownership Heterogeneity}

In order to investigate the influence of the IJV choice on firm innovation performance under the difference of firm ownership, the method of grouping the test of firm ownership is adopted here. Table 4 is the grouping of the regression results based on regression equation model (2).

Table 4 reports the results of OLS regression and Tobit regression, respectively. Comparing the results of state-owned firms in Model 4 and Model 8, the coefficients of the interaction terms IJV $\times$ RDIN in model 2 and model 6, related to private firms, are significantly negative at the level of $1 \%$. In addition, a Chow test was performed on the inter-group differences of IJV $\times$ RDIN regression coefficients in model 2 and model 4 , and IJV $\times$ RDIN regression coefficients in model 6 and model 8 , 
and it was found that the inter-group differences were all significant at the $10 \%$ level. Hypothesis 4 is therefore verified. This further indicates that, compared with state-owned firms, private firms lack the relative advantages in terms of policy and financial support, and lack the motivation for professional development and international expansion, which to some extent restrains their status and position in international cooperation, and to some extent strengthens the negative impact of the IJV choice on their innovation.

Table 4. The perspective of firm ownership heterogeneity.

\begin{tabular}{|c|c|c|c|c|c|c|c|c|}
\hline \multirow{3}{*}{ Variable } & \multicolumn{4}{|c|}{ OLS Regression } & \multicolumn{4}{|c|}{ Tobit Regression } \\
\hline & \multicolumn{2}{|c|}{ Private Firms } & \multicolumn{2}{|c|}{ State-Owned Firms } & \multicolumn{2}{|c|}{ Private Firms } & \multicolumn{2}{|c|}{ State-Owned Firms } \\
\hline & Model 1 & Model 2 & Model 3 & Model 4 & Model 5 & Model 6 & Model 7 & Model 8 \\
\hline RDIN & $\begin{array}{c}2.105 \\
(1.927)\end{array}$ & $\begin{array}{l}5.702 * * \\
(2.306)\end{array}$ & $\begin{array}{l}4.840 * * \\
(2.230)\end{array}$ & $\begin{array}{l}5.570 * \\
(3.081)\end{array}$ & $\begin{array}{c}2.124 \\
(1.876)\end{array}$ & $\begin{array}{l}5.774 * * \\
(2.239)\end{array}$ & $\begin{array}{l}5.562 * * \\
(2.158)\end{array}$ & $\begin{array}{l}5.783 * \\
(2.947)\end{array}$ \\
\hline IJV & $\begin{array}{l}-0.152 \\
(0.345)\end{array}$ & $\begin{array}{c}0.603 \\
(0.438)\end{array}$ & $\begin{array}{c}-0.763 * \\
(0.411)\end{array}$ & $\begin{array}{l}-0.645 \\
(0.538)\end{array}$ & $\begin{array}{l}-0.117 \\
(0.336)\end{array}$ & $\begin{array}{c}0.648 \\
(0.425)\end{array}$ & $\begin{array}{c}-0.858^{* *} \\
(0.400)\end{array}$ & $\begin{array}{l}-0.822 \\
(0.522)\end{array}$ \\
\hline $\mathrm{IJV} \times \mathrm{RDIN}$ & & $\begin{array}{c}-10.097^{* * *} \\
(3.743)\end{array}$ & & $\begin{array}{l}-1.510 \\
(4.371)\end{array}$ & & $\begin{array}{c}-10.230^{* * *} \\
(3.631)\end{array}$ & & $\begin{array}{l}-0.465 \\
(4.218)\end{array}$ \\
\hline _cons & $\begin{array}{c}-8.017^{* *} \\
(3.862)\end{array}$ & $\begin{array}{c}-7.795 * * \\
(3.772)\end{array}$ & $\begin{array}{c}-20.003^{* * *} \\
(4.887)\end{array}$ & $\begin{array}{c}-20.222^{* * *} \\
(4.956)\end{array}$ & $\begin{array}{c}-7.713 * * \\
(3.761)\end{array}$ & $\begin{array}{c}-7.492 * * \\
(3.660)\end{array}$ & $\begin{array}{c}-21.584 * * * \\
(4.748)\end{array}$ & $\begin{array}{c}-21.645^{* * *} \\
(4.779)\end{array}$ \\
\hline Control & yes & yes & yes & yes & yes & yes & yes & yes \\
\hline Year & yes & yes & yes & yes & yes & yes & yes & yes \\
\hline$N$ & 147 & 147 & 96 & 96 & 147 & 147 & 96 & 96 \\
\hline $\mathrm{F} / \mathrm{chi}^{2}$ & 1.887 & 2.273 & 4.795 & 4.497 & 31.26 & 38.98 & 71.88 & 71.89 \\
\hline $\mathrm{R}^{2} /$ PseudoR $^{2}$ & 0.199 & 0.242 & 0.529 & 0.529 & 0.056 & 0.0697 & 0.170 & 0.170 \\
\hline Adj. $R^{2} / 11$ & 0.094 & 0.136 & 0.418 & 0.412 & -263.8 & -260.0 & -175.0 & -175.0 \\
\hline Inter-group difference & \multicolumn{4}{|c|}{$0.057 *$} & \multicolumn{4}{|c|}{$0.035 * *$} \\
\hline
\end{tabular}

Notes: ${ }^{*} p<0.10,{ }^{* *} p<0.05,{ }^{* * *} p<0.01 ; t$-values are in parentheses.

To gain further insight into these findings, we plotted the related interaction results based on Model 2 and Model 4 (in Table 4). Figure 2 illustrates the interaction between the IJV choice and innovation performance in the firms' ownership. As shown in subfigure (a), the slope of the IJV choice on innovation performance is more negative when a firm is a privately-owned firm. In contrast, as shown in subfigure (b), the slope becomes positive when a firm is a state-owned firm. This contrast provides strong support for Hypothesis 4.

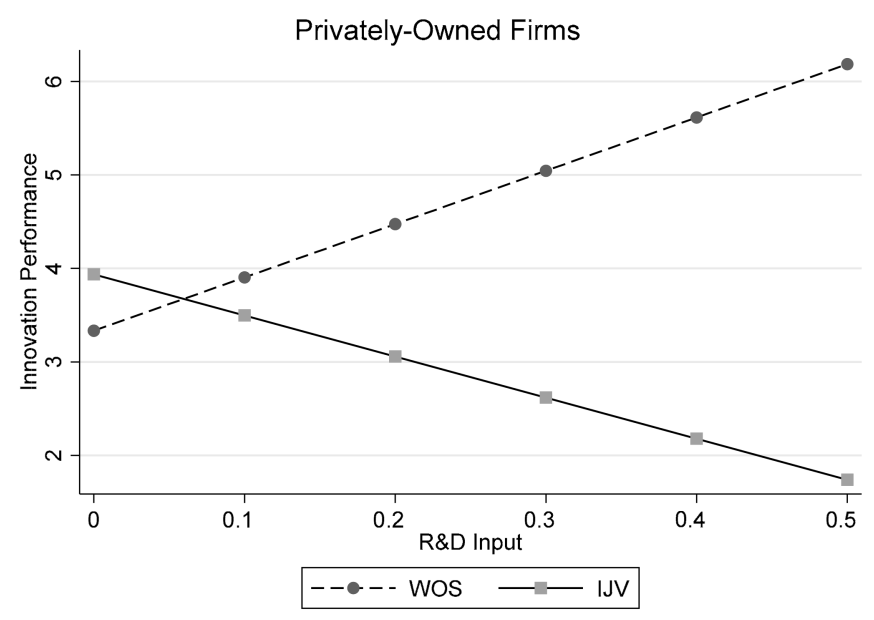

(a)

Figure 2. Cont. 


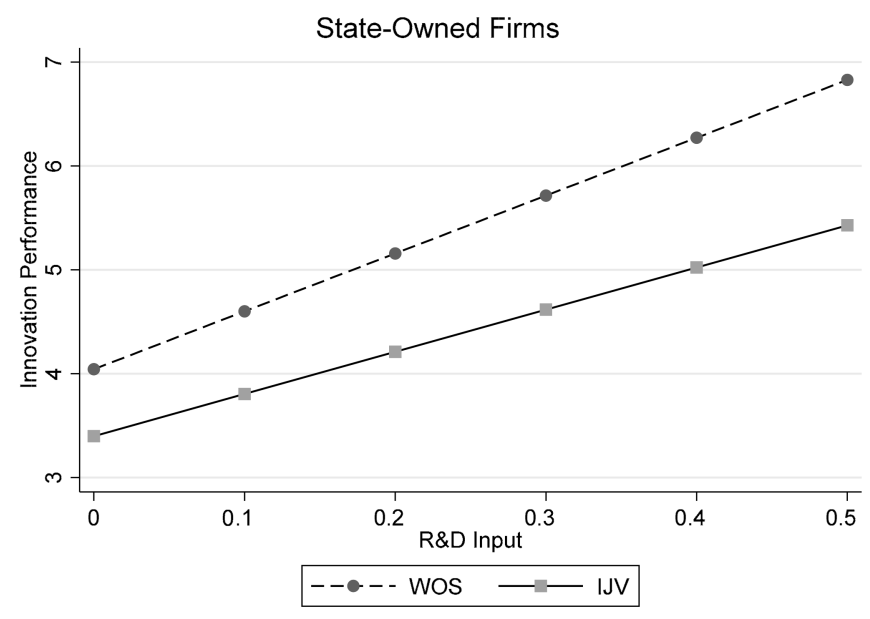

(b)

Figure 2. The moderating effects of entry mode choice on the relationship between R\&D input and innovation performance for firms with private and state ownership. As (a) The moderating effect for firms with private ownership and (b) The moderating effect for firms with state ownership.

4.4. The Influence of IJV on Firm Innovation Performance: A Perspective of Firm Internationalization Breadth Heterogeneity

In order to investigate the impact of IJV on firms' innovation performance under the differences in firms' internationalization breadth, the method of grouping test of firm internationalization breadth is adopted here. Table 5 displays the grouping regression results based on regression equation model (2).

Table 5. The perspective of firm internationalization breadth heterogeneity.

\begin{tabular}{|c|c|c|c|c|c|c|c|c|}
\hline \multirow{3}{*}{ Variable } & \multicolumn{4}{|c|}{ OLS Regression } & \multicolumn{4}{|c|}{ Tobit Regression } \\
\hline & \multicolumn{2}{|c|}{$\begin{array}{c}\text { Low } \\
\text { Internationalization } \\
\text { Breadth }\end{array}$} & \multicolumn{2}{|c|}{$\begin{array}{c}\text { High } \\
\text { Internationalization } \\
\text { Breadth }\end{array}$} & \multicolumn{2}{|c|}{$\begin{array}{c}\text { Low } \\
\text { Internationalization } \\
\text { Breadth }\end{array}$} & \multicolumn{2}{|c|}{$\begin{array}{c}\text { High } \\
\text { Internationalization } \\
\text { Breadth }\end{array}$} \\
\hline & Model 1 & Model 2 & Model 3 & Model 4 & Model 5 & Model 6 & Model 7 & Model 8 \\
\hline RDIN & $\begin{array}{c}1.973 \\
(1.512)\end{array}$ & $\begin{array}{l}5.027 * * \\
(2.124)\end{array}$ & $\begin{array}{c}16.845^{* * *} \\
(5.389)\end{array}$ & $\begin{array}{c}16.021^{* * * *} \\
(5.813)\end{array}$ & $\begin{array}{c}2.283 \\
(1.515)\end{array}$ & $\begin{array}{l}4.999 * * \\
(2.117)\end{array}$ & $\begin{array}{c}16.970 * * * \\
(4.761)\end{array}$ & $\begin{array}{c}16.204 * * * \\
(5.078)\end{array}$ \\
\hline IJV & $\begin{array}{c}-0.649 * * \\
(0.275)\end{array}$ & $\begin{array}{l}-0.168 \\
(0.361)\end{array}$ & $\begin{array}{l}-0.200 \\
(0.543)\end{array}$ & $\begin{array}{l}-0.471 \\
(0.867)\end{array}$ & $\begin{array}{c}-0.734^{* * *} \\
(0.277)\end{array}$ & $\begin{array}{l}-0.295 \\
(0.364)\end{array}$ & $\begin{array}{l}-0.168 \\
(0.480)\end{array}$ & $\begin{array}{l}-0.419 \\
(0.757)\end{array}$ \\
\hline IJV $\times$ RDIN & & $\begin{array}{c}-6.023^{* *} \\
(2.970)\end{array}$ & & $\begin{array}{c}3.747 \\
(9.305)\end{array}$ & & $\begin{array}{c}-5.407^{*} \\
(2.976)\end{array}$ & & $\begin{array}{c}3.476 \\
(8.122)\end{array}$ \\
\hline _cons & $\begin{array}{c}-10.190^{* * *} \\
(3.231)\end{array}$ & $\begin{array}{c}-10.218^{* * *} \\
(3.201)\end{array}$ & $\begin{array}{c}-19.417^{* * *} \\
(6.967)\end{array}$ & $\begin{array}{c}-19.487^{* * * *} \\
(7.036)\end{array}$ & $\begin{array}{c}-11.075^{* * *} \\
(3.264)\end{array}$ & $\begin{aligned}-11.045^{* * *} \\
(3.225)\end{aligned}$ & $\begin{array}{c}-19.786^{* * *} \\
(6.153)\end{array}$ & $\begin{array}{c}-19.849^{* * * *} \\
(6.144)\end{array}$ \\
\hline Control & yes & yes & yes & yes & yes & yes & yes & yes \\
\hline Year & yes & yes & yes & yes & yes & yes & yes & yes \\
\hline $\mathrm{N}$ & 181 & 181 & 62 & 62 & 181 & 181 & 62 & 62 \\
\hline $\mathrm{F} / \mathrm{chi}^{2}$ & 4.351 & 4.418 & 2.531 & 2.354 & 72.76 & 76.02 & 40.15 & 40.33 \\
\hline $\mathrm{R}^{2} /$ PseudoR $^{2}$ & 0.326 & 0.343 & 0.494 & 0.496 & 0.102 & 0.106 & 0.157 & 0.158 \\
\hline Adj. $R^{2} / 11$ & 0.251 & 0.265 & 0.299 & 0.285 & -320.7 & -319.1 & -107.5 & -107.4 \\
\hline Inter-group difference & \multicolumn{4}{|c|}{$0.015^{* *}$} & \multicolumn{4}{|c|}{$0.013 * *$} \\
\hline
\end{tabular}

Notes: ${ }^{*} p<0.10,{ }^{* *} p<0.05,{ }^{* * *} p<0.01 ; t$-values are in parentheses.

Table 5 reports the results of the OLS regression and Tobit regression. By comparing the results of high-internationalization firms in model 4 and model 8 , it can be shown that the coefficient of interaction item IJV $\times$ RDIN of low-internationalization firms in model 2 and model 6 is significantly negative at the $10 \%$ level. In addition, a Chow test was performed on the inter-group differences of the IJV $\times$ RDIN regression coefficients in model 2 and model 4 , and the IJV $\times$ RDIN regression coefficients in model 6 and model 8 , and it was found that the inter-group differences were all significant at the level of $5 \%$. Hypothesis 5 is therefore verified. This further shows that the early experience of 
internationalization based on export trade means that firms lack the accumulation of transnational operation capability brought about by the breadth of internationalization, and the premature choice of IJV has a significant inhibiting effect on the innovation efficiency of firms.

To gain further insight into these findings, we plotted the related interaction results based on Model 2 and Model 4 (in Table 5). Figure 3 illustrates the interaction between the IJV choice and innovation performance in the internationalization breadth of firms. As shown in subfigure (a), the slope of the IJV choice on the innovation performance is more negative when a firm is low in internationalization. In contrast, as shown in subfigure (b), the slope becomes positive when a firm is high in internationalization. This contrast provides strong support for Hypothesis 5.

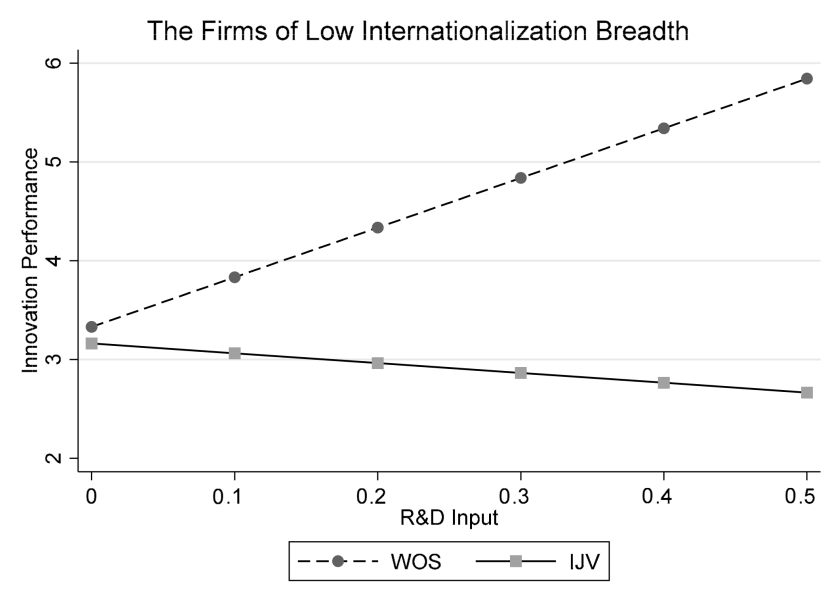

(a)

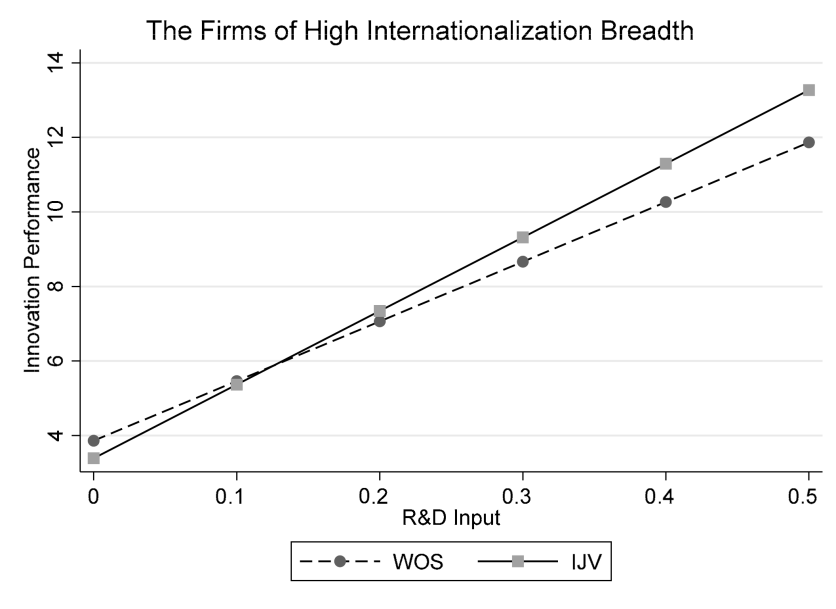

(b)

Figure 3. The moderating effects of entry mode choice on the relationship between R\&D input and innovation performance for firms with low and high internationalization breadth. As (a) The moderating effect for firms with low internationalization breadth and $(\mathbf{b})$ The moderating effect for firms with high internationalization breadth.

\section{Conclusions and Implications}

\subsection{Discussion}

Prior studies on the relationship between entry mode choice and performance are confined to the MNEs of developed countries. Especially in the context of technology-oriented OFDI-form EM-EMNs, prior studies lack further research on the determinants and effects of the entry mode choice of EM-MNES under institutional duality. In consideration of these reasons, under the background of the leapfrog 
development of latecomer firms' internationalization, based on the sample of Chinese manufacturing listed companies 'going out' from 2003 to 2015, by tracking the latest trends in international strategy choices of EM-EMNs for coordination challenges that have not been the focus of previous empirical research, we combined a conceptual model to examine the determinants of premature IJV choice under institutional duality, adding the additional tests on the relationship between the IJV choice and firms' innovation performance that have been neglected in prior studies.

\subsection{Conclusions}

Chinese manufacturing OFDI firms are in the stage of international leapfrog development; while being EM-EMNs confers a number of advantages, if their entry mode is not properly chosen, their innovation performance will be hard to achieve without the requisite capabilities and deliberation. Our empirical study also found that the premature IJV choices under institutional duality may have a negative impact on the innovation performance of Chinese firms which lack their capabilities' support. Moreover, when the firm is privately-owned or the internationalization breadth is low, the development of the firm's professional capabilities and internationalization capabilities will be more constrained, so the above-mentioned negative moderating effect of IJV on the efficiency of innovation transformation of firms will be more significant. Therefore, first of all, Chinese manufacturing firms should actively balance the needs of the organizations' institutional inertia and the host-countries' institutional quality in the choice of entry mode, and try their best to improve their high-level internationalization capabilities, such as cross-cultural management and joint governance. At the same time, the existing organizational practices and behavior patterns should be changed. In this way, the inherent potential and motivation of the IJV mode in innovation resource sharing and risk sharing can be stimulated as soon as possible.

\subsection{Suggestions for Future Research}

According to some critics, prior studies lack further research on the determinants and effects of the strategic choices of EM-MNEs $[18,19]$. It can be expected that, with the scale and speed of Chinese manufacturing firms 'going out', access to strategic resources and advanced technologies will become an increasingly important mission for them. Thus, the relationships between the strategic choices of internationalization under institutional duality and the performance of EM-MNEs will be a focal point for scholars, practitioners and policy makers in the future. According to the above suggestions, in future directions of research, considering that Chinese manufacturers will increasingly emphasize innovation growth, and foreign subsidiaries of EM-MNEs have the mission of entering a global innovation network and transferring knowledge and technology, we will further focus on the relationship between EM-MNEs' internationalization and parent innovation performance. However, considering EM-MNEs' dual strategy in terms of market expansion and technology innovation, the research on the relationship between EM-MNEs' internationalization and their performance will further divide performance into innovation performance and financial performance in the same period. Only through this distinction can we accurately grasp the characteristics of the dual mission and then reveal how EM-MNEs' internationalization factors 'jointly promote' or 'offset each other' in the two strategic performances.

\subsection{Research Limitations}

There are some limitations of our research. Because the internationalization of Chinese manufacturers is still at an early stage, the size and quality of the samples are not perfect, so the number of samples of listed manufacturing companies in Shanghai and Shenzhen that can be surveyed and chosen is limited. In order to deal with the limitation of the above sample size, and with the developments in the scale of Chinese firms' internationalization, and the improvements of Chinese firms' information disclosure and database platform construction, we will continue to track the internationalization development of China's OFDI manufacturing industry and expand the range of samples to non-listed manufacturing companies, to increase the applicability of the research results. 
Author Contributions: Conceptualization, C.W. and S.B.; data curation, S.B.; formal analysis, C.W. and S.B.; investigation, M.C. and S.Z.; methodology, C.W. and X.W.; project administration, C.W. and X.W.; resources, M.J.; software, S.B. and M.C.; supervision, M.J.; validation, C.W. and S.B.; visualization, S.B. and S.Z.; writing-original draft preparation, S.B. and M.C.; writing-review and editing, C.W. and S.B. All authors have read and agreed to the published version of the manuscript.

Funding: This research is partially sponsored by the National Social Science Fund of China (17BGL200), the Humanities and Social Sciences Planning Fund of the Ministry of Education (19YJA630085), the Jiangsu Planning Office of Philosophy and Social Science (18GLB025), and Jiangsu Province postgraduate scientific research innovation plan (KYCX20_0987).

Conflicts of Interest: The authors declare no conflict of interest.

\section{References}

1. Shen, R.; Mantzopoulos, V. China's “Going Out” policy: Inception, evolution, implication. J. Bus. Behav. Sci. 2013, 25, 121-136.

2. Hao, Y.; Guo, Y.; Guo, Y.; Wu, H.; Ren, S. Does outward foreign direct investment (OFDI) affect the home country's environmental quality? The case of China. Struct. Chang. Econ. Dyn. 2020, 52, 109-119. [CrossRef]

3. Deng, P. Chinese outward direct investment research: Theoretical integration and recommendations. Manag. Organ. Rev. 2013, 9, 513-539. [CrossRef]

4. Wang, H.Y.; Miao, L. CCG's Report on Chinese Enterprises Globalization (2018); Social Sciences Academic Press: Beijing, China, 2018.

5. De Perea, J.G.A.; Ramirezgarcia, C.; Cubo-molina, A.D. Internationalization business models and patterns of SMEs and MNEs: A qualitative multi-case study in the agrifood sector. Sustainability 2019, 11, 2755. [CrossRef]

6. Tung, R.L. The human resource challenge to outward foreign direct investment aspirations from emerging economies: The case of China. Int. J. Hum. Resour. Manag. 2007, 18, 868-889. [CrossRef]

7. Humphrey, A.A. The dilemma of institutional duality and multinational firms 1967-2017: Implications and future research. Multinatl. Bus. Rev. 2018, 26, 145-172.

8. Nell, P.C.; Puck, J.F.; Heidenreich, S. Strictly limited choice or agency? Institutional duality, legitimacy, and subsidiaries' political strategies. J. World Bus. 2015, 50, 302-311. [CrossRef]

9. Hillman, A.J.; Wan, W.P. The determinants of MNE subsidiaries' political strategies: Evidence of institutional duality. J. Int. Bus. Stud. 2005, 36, 322-340. [CrossRef]

10. Kostova, T.; Roth, K. Adoption of an organizational practice by subsidiaries of multinational corporations: Institutional and relational effects. Acad. Manag. J. 2002, 45, 215-233.

11. Lu, J.W.; Xu, D. Growth and survival of international joint ventures: An external-internal legitimacy perspective. J. Manag. 2006, 32, 426-448. [CrossRef]

12. Luo, Y.; Xue, Q.; Han, B. How emerging market governments promote outward FDI: Experience from China. J. World Bus. 2010, 45, 68-79. [CrossRef]

13. Luo, Y. Capability exploitation and building in a foreign market: Implications for multinational enterprises. Organ. Sci. 2002, 13, 48-63. [CrossRef]

14. Prange, C.; Verdier, S. Dynamic capabilities, internationalization processes and performance. J. World Bus. 2011, 46, 126-133. [CrossRef]

15. Brouthers, K.D.; Hennart, J.F. Boundaries of the firm: Insights from international entry mode research. J. Manag. 2007, 33, 395-425. [CrossRef]

16. Meyer, K.E. Institutions, transaction costs, and entry mode choice in Eastern Europe. J. Int. Bus. Stud. 2001, 32, 357-367. [CrossRef]

17. Brouthers, K.D.; Brouthers, L.E.; Werner, S. Transaction cost-Enhanced entry mode choices and firm performance. Strat. Manag. J. 2003, 24, 1239-1248. [CrossRef]

18. Cui, L.; Jiang, F.; Stening, B.W. The entry-mode decision of Chinese outward FDI: Firm resources, industry conditions, and institutional forces. Thunderbird Int. Bus. Rev. 2011, 53, 483-499. [CrossRef]

19. Wu, J.; Wang, C.; Hong, J.; Piperopoulos, P.; Zhuo, S. Internationalization and innovation performance of emerging market enterprises: The role of host-country institutional development. J. World Bus. 2016, 51, 251-263. [CrossRef] 
20. Florida, R. The globalization of R\&D: Results of a survey of foreign-affiliated R \& D laboratories in the USA. Res. Policy 1997, 26, 85-103.

21. Wu, C.; Huang, F.; Huang, C.; Zhang, H.J.S. Entry mode, market selection, and innovation performance. Sustainability 2018, 10, 4222. [CrossRef]

22. Tempel, A.; Edwards, T.; Ferner, A.; Mullercamen, M.; Wachter, H. Subsidiary responses to institutional duality: Collective representation practices of US multinationals in Britain and Germany. Hum. Relat. 2006, 59, 1543-1570. [CrossRef]

23. Zhang, Y.; Zhao, W.; Ge, J. Institutional duality and political strategies of foreign-invested firms in an emerging economy. J. World Bus. 2016, 51, 451-462. [CrossRef]

24. Chung, C.C.; Xiao, S.S.; Lee, J.Y.; Kang, J. The interplay of top-down institutional pressures and bottom-up responses of transition economy firms on FDI entry mode choices. Manag. Int. Rev. 2016, 56, 699-732. [CrossRef]

25. Cui, L.; Jiang, F. Ownership decisions in Chinese outward FDI: An integrated conceptual framework and research agenda. Asian Bus. Manag. 2009, 8, 301-324. [CrossRef]

26. Li, J.; Xia, J.; Shapiro, D.; Lin, Z. Institutional compatibility and the internationalization of Chinese SOEs: The moderating role of home subnational institutions. J. World Bus. 2018, 53, 641-652. [CrossRef]

27. Voss, H.; Buckley, P.J.; Cross, A.R. The impact of home country institutional effects on the internationalization strategy of Chinese firms. Multinatl. Bus. Rev. 2010, 18, 25-48. [CrossRef]

28. Tang, J.; Tang, Z.; Cowden, B.J. Exploring the relationship between entrepreneurial orientation, ceo dual values, and sme performance in state-Owned vs. nonstate-Owned enterprises in china. Entrep. Theory Pract. 2017, 41, 883-908. [CrossRef]

29. Deng, P. The internationalization of Chinese firms: A critical review and future research. Int. J. Manag. Rev. 2012, 14, 408-427. [CrossRef]

30. Cui, L.; Jiang, F. FDI entry mode choice of Chinese firms: A strategic behavior perspective. J. World Bus. 2009, 44, 434-444. [CrossRef]

31. Williamson, O.E. The Economic Institution of Capitalism; Free Press: New York, NY, USA, 1998.

32. Rindfleisch, A.; Heide, J.B. Transaction cost analysis: Past, present, and future applications. J. Mark. 1997, 61, 30-54. [CrossRef]

33. Brouthers, K.D.; Brouthers, L.E.; Werner, S. Real options, international entry mode choice and performance. J. Manag. Stud. 2008, 45, 936-960. [CrossRef]

34. Tallman, S.; Fladmoelindquist, K. Internationalization, globalization, and capability-based strategy. Calif. Manag. Rev. 2002, 45, 116-135. [CrossRef]

35. Anderson, E.; Gatignon, H. Modes of foreign entry: A transaction cost analysis and propositions. J. Int. Bus. Stud. 1986, 17, 1-26. [CrossRef]

36. Gatignon, H.; Anderson, E. The multinational corporation's degree of control over foreign subsidiaries: An empirical test of a transaction cost explanation. J. Law Econ. Organ. 1988, 4, 305-336.

37. Folta, T.B.; Miller, K.D. Real options in equity partnerships. Strat. Manag. J. 2002, 23, 77-88. [CrossRef]

38. Meyer, K.E.; Nguyen, H.V. Foreign investment strategies and sub-national institutions in emerging markets: Evidence from Vietnamt. J. Manag. Stud. 2005, 42, 63-93. [CrossRef]

39. Shirodkar, V.; Konara, P. Institutional distance and foreign subsidiary performance in emerging markets: Moderating effects of ownership strategy and host-country experience. Manag. Int. Rev. 2017, 57, 179-207. [CrossRef]

40. Kostova, T.; Zaheer, S. Organizational legitimacy under conditions of complexity: The case of the multinational enterprise. Acad. Manag. Rev. 1999, 24, 64-81. [CrossRef]

41. Wu, Z.; Salomon, R. Does imitation reduce the liability of foreignness? Linking distance, isomorphism, and performance. Strat. Manag. J. 2016, 37, 2441-2462. [CrossRef]

42. Chao, M.C.; Kumar, V. The impact of institutional distance on the international diversity-performance relationship. J. World Bus. 2010, 45, 93-103. [CrossRef]

43. Brouthers, K. Institutional, cultural and transaction cost influences on entry mode choice and performance. J. Int. Bus. Stud. 2002, 33, 203-221. [CrossRef]

44. Shenkar, O. Cultural distance revisited: Towards a more rigorous conceptualization and measurement of cultural differences. J. Int. Bus. Stud. 2001, 32, 519-535. [CrossRef]

45. Oh, K.; Ryu, Y.S. FDI, institutional quality, and bribery: An empirical examination in China. Sustainability 2019, 11, 4023. [CrossRef] 
46. Meyer, K.E.; Estrin, S.; Bhaumik, S.K.; Peng, M.W. Institutions, resources, and entry strategies in emerging economies. Strat. Manag. J. 2009, 30, 61-80. [CrossRef]

47. Drejer, I.; Jorgensen, B.H. The dynamic creation of knowledge: Analysing public-private collaborations. Technovation 2005, 25, 83-94. [CrossRef]

48. Casillas, J.C.; Morenomenendez, A.M. Speed of the internationalization process: The role of diversity and depth in experiential learning. J. Int. Bus. Stud. 2014, 45, 85-101. [CrossRef]

49. Li, M.H.; Cui, L.; Lu, J. Varieties in state capitalism: Outward FDI strategies of central and local state-owned enterprises from emerging economy countries. J. Int. Bus. Stud. 2014, 45, 980-1004. [CrossRef]

50. Shi, W.; Markoczy, L.; Stan, C.V. The continuing importance of political ties in China. Acad. Manag. Pers. 2014, 28, 57-75. [CrossRef]

51. Cui, L.; Jiang, F. State ownership effect on firms' FDI ownership decisions under institutional pressure: A study of Chinese outward-investing firms. J. Int. Bus. Stud. 2012, 43, 264-284. [CrossRef]

52. Hong, J.; Wang, C.; Kafouros, M. The role of the state in explaining the internationalization of emerging market enterprises. Br. J. Manag. 2015, 26, 45-62. [CrossRef]

53. Buckley, P.J.; Clegg, L.J.; Cross, A.R.; Liu, X.; Voss, H.; Zheng, P. The determinants of Chinese outward foreign direct investment. J. Int. Bus. Stud. 2007, 38, 499-518. [CrossRef]

54. Duanmu, J.L. Firm heterogeneity and location choice of Chinese multinational enterprises (MNEs). J. World Bus. 2012, 47, 64-72. [CrossRef]

55. Sapienza, H.J.; Autio, E.; George, G.; Zahra, S.A. A Capabilities perspective on the effects of early internationalization on firm survival and growth. Acad. Manag. Rev. 2006, 31, 914-933. [CrossRef]

56. Hitt, M.A.; Bierman, L.; Uhlenbruck, K.; Shimizu, K. The importance of resources in the internationalization of professional service firms: The good, the bad, and the ugly. Acad. Manag. J. 2006, 49, 1137-1157. [CrossRef]

57. Makino, S.; Delios, A. Local knowledge transfer and performance: Implications for alliance formation in Asia. J. Int. Bus. Stud. 1996, 27, 905-927. [CrossRef]

58. Kafouros, M.; Buckley, P.J.; Clegg, J. The effects of global knowledge reservoirs on the productivity of multinational enterprises: The role of international depth and breadth. Res. Policy 2012, 41, 848-861. [CrossRef]

59. Barkema, H.G.; Vermeulen, F. International expansion through start-up or acquisition: A learning perspective. Acad. Manag. J. 1998, 41, 7-26.

60. Lewbel, A. Constructing instruments for regressions with measurement error when no additional data are available, with an application to patents and R\&D. Econometrica 1997, 65, 1201-1214.

61. Cornaggia, J.; Mao, Y.; Tian, X.; Wolfe, B. Does banking competition affect innovation. J. Financ. Econ. 2015, 115, 189-209. [CrossRef]

62. Hsu, C.; Boggs, D.J. Internationalization and performance: Traditional measures and their decomposition. Multinatl. Bus. Rev. 2003, 11, 23-50. [CrossRef]

63. World Bank. The Worldwide Governance Indicators (WGI). Available online: http://info.worldbank.org/ governance/wgi/index.aspx\#home (accessed on 15 July 2020).

64. Tihanyi, L.; Griffith, D.A.; Russell, C.J. The effect of cultural distance on entry mode choice, international diversification, and Mne performance: A meta-analysis. J. Int. Bus. Stud. 2005, 36, 270-283. [CrossRef]

65. Hoskisson, R.O.; Johnson, R.A. Research notes and communications corporate restructuring and strategic change: The effect on diversification strategy and R \& D intensity. Strat. Manag. J. 1992, 13, 625-634.

66. Kyungsuk, L.; Taewoo, R. Proactive divestiture and business innovation: R\&D input and output performance. Sustainability 2020, 12, 3874.

67. Allen, L.; Pantzalis, C. Valuation of the operating flexibility of multinational corporations. J. Int. Bus. Stud. 1996, 27, 633-653. [CrossRef]

68. Hitt, M.A.; Hoskisson, R.E.; Kim, H. International diversification: Effects on innovation and firm performance in product-diversified firms. Acad. Manag. J. 1997, 40, 767-798.

69. Child, J.; Rodrigues, S.B. The internationalization of Chinese Firms: A case for theoretical extension? Manag. Organ. Rev. 2005, 1, 381-410. [CrossRef]

(C) 2020 by the authors. Licensee MDPI, Basel, Switzerland. This article is an open access article distributed under the terms and conditions of the Creative Commons Attribution (CC BY) license (http://creativecommons.org/licenses/by/4.0/). 